\title{
Legal Protection for Copyrighted Song Holders for Songs Used by Other Parties Illegally
}

\author{
Berthania Pitaloka Puspaasri ${ }^{1}$, Budiharto ${ }^{2}$, Ro'fah Setyowati $^{3}$ \\ \{berthaniaapitaloka@yahoo.co.id ${ }^{* 1}$, budiharto@live.undip.ac.id ${ }^{2}$, rofah@live.undip.ac.id ${ }^{3}$ \} \\ Fakultas Hukum, Universitas Diponegoro, Jl. Prof. H. Soedarto, S.H., Semarang, Indonesia 50275 1,2,3
}

\begin{abstract}
A song is one of the works that comes from the human thought process which is then manifested in the form of creation that can be heard its beauty in the unity of lyrics, notations, and instruments. The creation of songs requires absolute rights, namely copyright to provide legal protection for the creator. The purpose of this research is to know and understand the forms of legal protection for copyright holders of songs and analyze the responsibilities of those who use and carry out commercial activities of copyrighted music. The method used is a normative juridical approach, with the specifications of descriptive analysis. Data are collected from the secondary data, with the analytical method of Qualitative Analysis. Based on the results of the study, it is revealed that the form of legal protection for copyright holders for songs commercialized by other parties in the form of registration of the work is given the right to sue against copyright infringers, and impose sanctions in accordance with copyright infringement committed. The responsibility of those who use and carry out commercial activities without permission is to pay a sum of money in compensation for the losses suffered and return the title song that was replaced to the original one.
\end{abstract}

Keywords: Protection, Copyright, Song.

\section{Introduction}

\subsection{Background}

In making a creation to produce a copyrighted work, it is necessary to think through the ideas and ideas of the creator. These ideas can be in the form of books, songs or music, works of art, photography, drama, poetry, and others. Due to a large number of works needed by the creator, the creation should belong to the personal creator of the work.[1] Therefore, a copyright must be given as part of Intellectual Property Rights to protect and defend the ideas and creators' ideas.

Copyright consists of economic rights and moral rights. Economic rights are the rights to obtain economic benefits for the Work and Related Right products. Moral Rights are rights inherent in the Creator or Actor that cannot be removed or deleted without any reason, even though Copyright or Related Rights have been transferred. Copyright protection is not given to ideas or ideas because the copyrighted work must have a distinctive form, is personal, and shows authenticity as a work that is born based on ability, creativity, or expertise, so that the work can be seen, read, or heard.[2]

In Indonesia, the regulation of protection of creation began from the entry into force of Auteurswet 1912 (Stb. 1912 No. 600), 23 September 1912 during the reign of the Dutch East 
Indies. After Indonesia gained its independence and the National Copyright Act was first formed in 1982, which changed several times; however, the musical works are still listed as works protected by copyright.[3] Along with the times, the Copyright Act continues to change, beginning with Law Number 6 of 1982 concerning Copyright, then the law was changed to Law Number 7 of 1987 concerning Copyright, subsequently changed to Law Number 12 of 1997 concerning Copyright, was later changed again to Law Number 19 of 2002 concerning Copyright, and finally changed to Law Number 28 of 2014 concerning Copyright which is still valid today. [4]

Cases related to copyright infringement of recent songs that have occurred are Reporting the songwriter of children's songs Tita Nurwati or broadly known as Titta Rizky against PT. Global Music Digital Era (GMED) to East Java Regional Police. This happened because PT. Digital Music Global Era which has uploaded and commercialized songs by attracting economic rights through Ring Backtone (RBT) without Tita Nurwati's permission as the owner as well as the creator and procedure of the song Galau and Allah. PT. Global Music Digital Era violated articles including copyright infringement Article 113 paragraph (2), Jo Article 9 paragraph (1) letter d, Jo Article paragraph (3) RI Law Number 28 of 2014.

The case between Tita Nurwati and PT. The Digital Music Global Era (GMED) above is one of the many copyright violations of ownership of a song. So, many cases of copyright infringement that occurred in Indonesiais something that is worrying the creators of a work. A form of creativity someone who should be valued, it is used as an opportunity to seek benefits for various parties who are not responsible. This is a violation of the Copyright Act.

Based on the above problems, the authors are interested in conducting further research on the issue of copyright infringement of the song that occurred between Tita Nurwati as the song owner and PT. Global Music Digital Era (GMED) as the party that uploads and commercializes songs through Ring Backtone (RBT) without permission and legal remedies under the title "Legal Protection for Copyrighted Song Holders for Songs Used by Other Parties Illegally."

\subsection{Formulation of the problem}

Based on the background stated above, the problems that will be examined in this study are:

1. What is the form of legal protection for copyright holders for songs commercialized by other parties?

2. What are the responsibilities of those who use and carry out commercial activities of copyright from the copyright owner without permission?

\section{Method}

The method of dependency used in the writing of this law is normative juridical. This legal research specification uses descriptive analytical research. This research is considered as normative, so the data needed in this study is secondary data. In this study, the method of analysis used by the writer is qualitative analysis. 


\section{Results and Discussion}

\subsection{Legal Protection for Copyright Holders of Songs Commercialized by Other Parties}

In a cultural perspective, music as an artistic element of culture cannot be separated from the social reality of the dynamics of life that develops in the society concerned. As an art, music cannot be separated from life. Even the intrinsic values of a musical work (song) on a certain scale are a reflection that represents a picture of the socio-cultural conditions associated with other fields of life, including the cultural security of a nation [5].

Music that always goes hand in hand with human life up to the present day continues to experience significant developments and changes. These conditions resulted in increasingly intense competition in the world of music and the people involved in it. tThe competition occurs haphazardly, resulting in the emergence and occurrence of violations of the law, for example such as piracy, recording, arranging, duplicating, transferring manifest and change the composition of part or all of a song without the permission of the owner.

\subsubsection{The Case of Tita Nurwati's Song Sad and God Copyright Infringement Position conducted by PT. Digital Music Global Era (GMED)}

Based on the results of an interview with Rozi Maulana, [6] advocate at the Law Office of Togar Situmorang \& Associates, this case began where Tita Nurwati was the legitimate creator and producer of the song Galau and Allah sung by a young artist named Rayvelin. Then, PT. Global Music Digital Era as the label that houses songs of Tita Nurwati has intentionally violated the law by commercializing and uploading it without Tita Nurwati's permission as the owner, creator, and legal producer of the song that has been registered with the Director General of Intellectual Property.

PT. Global Music Digital Era as the label of Tita Nurwati is indicated to have carried out commercial activities and uploaded without permission via Youtube and used the song as RBT (Ringback Tone) in several providers namely Telkomsel, Indosat and XL. In addition, Tita Nurwati as the songwriter did not know that PT. Digital Music Global Era has replaced the title song 'Allah' with the name 'Sholawat'. Then, there are indications of other violations, namely PT. Global Music Digital Era falsified the signature of the contract, this is because Tita Nurwati as the songwriter felt never signed a contract with any party, and the copy of the contract that was said to have been signed was not held by Tita Nurwati so Tita Nurwati did not know the contents of the contract.

Therefore, Tita Nurwati along with her lawyer, Togar Situmorang, reported PT. Digital Music of the Digital Era to the East Java regional police according to the Report Proof (TBL) Number: TBL/26/VII/2018/SUS/East Java and dated July 25, 2018.

From the series of cases above, the position can be concluded that PT. Global Music Era Diigital has committed copyright infringement against Tita Nurwati by commercializing and uploading songs to Youtube and changing the title song "Allah" to "Sholawat" without permission and there are indications that PT. Digital Music Global Era has falsified Tita Nurwati's signature.

\subsubsection{Infringed Author Rights}

Copyright is one of the rights contained in Intellectual Property Rights (IPR). Unlike other rights in Intellectual Property Rights (IPR) which give full rights to own and control a work of creation, copyright exists to prevent and protect the work of others. Copyright is born 
automatically since the creation is realized and is embedded in the creator until a certain period. That is what gives birth to the moral rights of the creator of his creation.

As the creator and rightful owner of the song Galau and Allah, Tita Nurwati has the absolute right to protect and maintain her creation for her exclusive rights as creator of a copyrighted work, which have been violated by PT. Digital Music of the Digital Era as explained in Act Number 28 of 2014 concerning Copyright Article 4 and has also changed the song title without the author's permission, so that the integrity of the moral rights of the creator has also been violated as provided for in Law Number 28 of 2014 concerning Copyright Article 5.

Besides that, PT. Global Music Digital Era also intentionally commercialized and uploaded without the permission of Tita Nurwati's song via Youtube and used the song as RBT (Ringback Tone) in several providers namely Telkomsel, Indosat and XL. Due to these conditions, economic rights which are one of the exclusive rights of Tita Nurwati are not fulfilled as stated in Law Number 28 of 2014 concerning Copyright Article 9.

In addition to changing the song title and intentionally commercializing without the author's song permission, PT. Digital Music Global Era is also suspected of violating the law by faking contract signatures. Thus PT. Global Music Digital Era has committed acts of lawlessness that enter the realm of criminal law.

To better know and understand about copyright infringement committed by PT. Digital Music of the Digital Era to Tita Nurwati, the writer conducted an interview with Rinitami Njatriani, [7] as a lecturer at the Faculty of Law of Diponegoro University who was competent and expert in studying Intellectual Property Rights, especially regarding Copyright. According to him, the cause of copyright infringement in the case is because first, law enforcement related to copyright is not maximal in this case the right to receive royalties. Second, the point is that people will do anything to be able to meet the needs that they think will never be enough, including by doing copyright infringement. Third, the Government needs to echo outreach to the general public, especially people who own the work with the theme of the importance of registering the work.

From the description above, it can be concluded that PT. Digital Music Global Era has violated the rights possessed by Tita Nurwati as a legitimate songwriter namely exclusive rights including moral rights and economic rights.

\subsubsection{Legal Protection for Copyright Holders under Law Number 28 of 2014 Regarding Copyright}

Legal protection given to the people of Indonesia is an implementation of the principles of recognition and protection of human dignity and sources that originate from Pancasila and the principles of the rule of law based on Pancasila. Legal protection is essentially every person has the right to get protection from the law. Almost all legal relations must receive protection from the law.

The results of a copyrighted work are produced and developed on the basis of the thought and creativity of the creator. Thus, it requires a very long time to produce a work of creation.In addition, the work of creative works also analyzes the various effects contained therein. So, legal protection for song and music composers or even legal protection for songs and music is a common and absolute thing because in making a copyrighted work there are consequences that can be caused.

Legal protection of copyright is inseparable from the notion of copyright that is based on Law Number 28 of 2014 concerning Copyright Article 1 Paragraph 1, which contains: 
"Copyright is the exclusive right of the creator which arises automatically based on the declarative principle after a work is realized in tangible form without reducing restrictions in accordance with statutory provisions."

Then it is reaffirmed in Law Number 28 of 2014 concerning Copyright Article 4 which explains:

"Copyright as referred to in Article 3 letter A is an exclusive right consisting of moral rights and economic rights."

An exclusive right in a copyright is a privilege granted to the creator for his work. Absolute exclusive rights are reserved for the creator so that other parties are not allowed to use a copyrighted work without the author's permission. In the case of the song Galau and Allah by Tita Nurwati, her exclusive rights as the creator of the titles of the two songs were violated by PT. Global Music Digital Age. Because PT. Digital Music Global Era did not fulfill Tita Nurwati's moral and economic rights by intentionally commercializing without the permission of Tita Nurwati's song via Youtube and using the song as RBT (Ringback Tone) in several providers, replacing the title song 'Allah' with the name 'Sholawat' without Tita Nurwati's notice and permission.

Viewed from the object, economic rights include the right to announce and the right to reproduce. Announcement is reading, broadcasting, exhibiting, selling, distributing or distributing a work by using any tools including internet media, or doing it in any way so that a work can be read, heard or seen by others. Whereas propagation is an increase in the number of a work, both in whole and in a substantial part, by using the same or unequal materials, including permanent or contemporary outsourcing. [8]

The moral rights include the right of the creator to put his name in the work and the right of the creator to prohibit others from changing their work, including the title or content of the song. the moral rights system basically comes from the fact that the copyrighted work is a reflection of the personality of the creator.

The systematic arrangement in Law Number 28 Of 2014 concerning Copyright regulates the explanation and protection of the work. However, there are no rules that clearly and specifically study the creation of songs or music. Law Number 28 of 2014 concerning Copyright only explains very little about the creation of songs and music. One of them was mentioned in Law Number 28 of 2014 concerning Copyright article 40 paragraph (1).

In this case, Tita Nurwati's song Galau and Allah belongs to a protected work. Because based on the results of an interview with Rozi Maulana [6], advocate at Togar Situmorang \& Associates Law Office that the song Galau and Allah owned by Tita Nurwati has been popular with the public and registered with the Directorate General of Intellectual Property Rights (DJKI). Thus, PT. Digital Music Global Era who intentionally commercialized and changed the song title without permission from Tita Nurwati has violated copyright law.

Talking about the registration of a work is actually not determined by the Copyright Act required to be registered. The fact that a work is not registered raises many problems regarding law violations of the work. Copyright registration should have several benefits, namely:[9]

1. Anticipating the existence of other parties who use without permission;

2. Anticipating disputes with copyright holders;

3. Requesting the cancellation of the recording of our Work by another party which is done without rights. 
The registration of the work is carried out at the Directorate General of Intellectual Property Rights, Ministry of Law and Human Rights of the Republic of Indonesia. By registering these songs officially, it will record the name, address, and title of the work in question in the public register of the work that was held specifically for this purpose. Records are made on the public register of works and official announcements are made in the addition of state news. The procedure for registering a work is as follows:[10]

a. Application for registration of a work must be submitted by filling out the form provided in Indonesian and typed in duplicate

b. Applicants must attach:

1. Special power of attorney if the application is filed through a power of attorney.

2. For song creation, examples of the creation are 10 pieces of notation or poetry.

3. An official copy of the notary deed of establishment of a legal entity or a photocopy of it, if the applicant is a legal entity.

4. Photocopy of residence identification card.

5. Proof of payment of application fees.

c. In the case of an application for registration of a work in which the copyright holder is not the creator, the applicant is required to attach proof of the transfer of copyright.

According to Rinitami Njatriani,[7] in the practice of copyright, there is a dualism of registration of creation. The first opinion says that copyright does not need to be registered because it automatically belongs to the creator, Tita Nurwati. The second says that copyrights need to be registered in order to get a Copyright Certificate. Copyright certificates can be used as evidence so that there is legal certainty that the copyright certificate from Tita Nurwati really belongs to her, so that it has a guarantee of legal certainty. However, law enforcement related to copyright has not been maximally carried out by law enforcement. Thus, if there are problems related to copyright cases, especially those that occur with Tita Nurwati, it is still considered to be of little importance and is ignored by the community and law enforcement.

From the description that has been described above, it can be concluded that PT. Global Music Digital Era has committed a copyright violation against Tita Nurwati by commercializing and uploading songs to Youtube and changing the title song "Allah" to "Sholawat" without permission so that it has violated its exclusive rights namely moral rights and economic rights. The form of legal protection for Tita Nurwati's copyright case has been regulated in Law Number 28 of 2014 concerning Copyright, but its implementation has not been maximized.

\subsection{Responsibilities of those who use and carry out commercial activities of copyright from the copyright owner without permission}

Responsibility is human self-awareness of all intentional and unintentional behavior and actions. Responsibility must also come from the heart and self-will for the obligations that must be accounted for.[11] To obtain or increase awareness of the responsibility must be pursued and sought through education, counseling, exemplary, and piety to God Almighty.

Speaking of civil law, responsibility cannot also be separated from Intellectual Property Rights. Every person or legal entity that has a relationship with Intellectual Property Rights, especially in the field of song must be responsible with his creation and respect the creation of others so that legal problems do not occur in the future. 


\subsubsection{Law Enforcement for Parties Using and Conducting Commercial Copyright Activities from Copyright Owners without Permit under Law Number 28 of 2014 Regarding Copyright}

Law enforcement against copyright is not something that stands alone apart from the performance of law enforcement in general. Law enforcement against copyright is an integral part of the law enforcement system in the State of Indonesia. The law functions as a means of protecting human interests. For human interests to be protected, laws must be implemented effectively. Law enforcement can take place normally, peacefully and can occur due to violation of the law. In this case, the law violated must be upheld. Through law enforcement, this law can become reality.[3]

In this case a violation of copyright law committed by PT. Digital Music Global Era, they have commercialized and uploaded without permission via Youtube and is used as an RBT (Ringback Tone) in several providers namely Telkomsel, Indosat along with XL song titled Troubled and God owned by Tita Nurwati. In addition to commercializing and uploading without permission, PT. Digital Music Global Era is also indicated to have replaced the title song 'Allah' with the name 'Sholawat' without notice and with the permission of Tita Nurwati as the song owner. This situation proves that PT. Digital Music Global Era violates the provisions of Law Number 28 Of 2014 concerning Copyright Article 5.

If PT. Global Music Digital Era is proven to have violated the law on copyright owned by Tita Nurwati and thus can be ensnared by the provisions of Law No. 28 of 2014 concerning Copyright Article 113 paragraph (2).

In addition to changing the song title and intentionally commercializing without the author's song permission, PT. Global Music Digital Era is suspected of violating the law by faking a contract signature. Tita Nurwati said she had never signed a contract with any party, and Tita Nurwati never held a copy and did not know the contents of the contract. Thus, if PT. Global Music Digital Era is proven to have violated the law, so it can be snared by the Indonesian Criminal Code Article 264 which is punishable by a maximum imprisonment of eight years.

Law Number 28 of 2014 concerning Copyright regulates that a copyrighted work will receive legal protection if the work of each creator's work can show its authenticity. This principle confirms that every copyrighted work will not be protected by Law Number 28 of 2014 concerning Copyright if a copyrighted work is a copy of someone else's.

From the description above, it can be concluded that law enforcement against violations that have been committed by PT. Digital Music Global Era must be upheld as stipulated in Law No. 28 of 2014 concerning Copyright because the songs created by Tita Nurwati have been registered at the Directorate General of Intellectual Property which of course gets legal protection.

\subsubsection{Case Dispute Settlement between Tita Nurwati and PT. Global Music Digital Age}

In this case the problem that occurred between Tita Nurwati with PT. The Global Music Digital Age can be resolved through two legal instruments. Law Number 28 Of 2014 concerning Copyright regulates and provides two legal instruments that can be used to crack down on perpetrators of Copyright infringement on songs or music, namely through means of criminal and civil law instruments. In addition to these instruments, Law Number 28 of 2014 concerning Copyright Article 95 also regulates dispute resolution by litigation and nonlitigation, including through alternative dispute resolution, arbitration, and courts. 
In resolving this case, the parties should choose to settle disputes outside the court (non litigation) through Alternative Dispute Resolution namely mediation. Mediation is carried out with the help of the mediator. Mediation is the right choice because settlement in a judicial institution takes a lot of timcosts higher, the desired decision is difficult to obtain, and causes new problems so that mediation is considered to be an effective choice to reconcile the parties to the dispute. Mediation is carried out to obtain agreement from the parties to the dispute so that it is reached (Win-Win solution) which is a decision where no one wins or loses in the dispute.

From the explanation above, it can be concluded that law enforcement against copyright infringement on songs created by Tita Nurwati where PT. Digital Music Global Era must be responsible for his actions by paying a sum of money in compensation for the losses suffered by Tita Nurwati and returning the song titles that were replaced to the original titles. The parties agreed not to proceed with the dispute on the court line so that the end of the dispute was peace.

\section{Conclusion}

Based on the results of research and discussion can be concluded include the following:

1. The forms of legal protection for copyright holders for songs commercialized by other parties including registration of works in the Directorate General of Intellectual Property (DG Intellectual Property Rights), giving the right to sue copyright infringers, and imposing sanctions in accordance with copyright infringement committed. In this case, PT. Global Music Digital Era has committed copyright infringement by changing the title of the song without the author's permission so that it violates the moral rights of the creator. In addition, it has violated Tita Rizky's economic rights as the copyright holder by intentionally commercializing and uploading without Tita Nurwati's permission via Youtube and using the song as RBT (Ringback Tone) in several providers. Therefore, PT. Global Music Digital Era must be sanctioned in accordance with copyright infringement committed.

2. The responsibility of the party that uses and conducts commercial activities of the copyright of the copyright owner without permission, that is by paying a sum of money as compensation for the injured party and returning the song title that was replaced to the original one.. In this case, PT. Digital Music Global Era violated the copyright of Tita Rizky as the injured party because the song had been used without permission by PT. Global Music Digital Era for commercial purposes and change the title song "Allah" to "Sholawat", so that PT. Digital Music Global Era must be responsible for paying a sum of compensation to Tita Nurwati and returning the title song to "Allah", as the original one.

\section{Suggestion}

Based on the results of the study, the author can provide several suggestions including the following:

1. For songwriters 
In an effort to provide optimal legal protection, it is expected to register the work which constitutes a guarantee to obtain legal protection in the event of acts of violation used by other parties for for commercial activities. 


\section{References}

[1] G. Supramono, Hak Cipta dan Aspek-Aspek Hukumnya. Jakarta: Rineka Cipta, 2010.

[2] E. Djaja, Hukum Hak Kekayaan Intelektual. Jakarta: Sinar Grafika, 2009.

[3] O. Hasibuan, Hak cipta di Indonesia: tinjauan khusus, hak cipta lagu, neighbouring rights, dan collecting society. Bandung: Alumni, 2008.

[4] Law Number 28 of 2014 concerning Copyright. .

[5] A. Palit, "No TitleMusik dan Strategi Kebudayaan," 2011. [Online]. Available: https://www.tribunnews.com/tribunners/2011/02/10/musik-dan-strategi-kebudayaan-1.

[6] Interview with Rozi Maulana, Advocate at Togar Situmorang \& Associates Law Office. (By telephone, September 2, 2019). .

[7] Interview with Rinitami Njatrijani, Lecturer at the Faculty of Law, Diponegoro University (September 29, 2019, in the Lecturer Room at the Faculty of Law, Diponegoro University). .

[8] H. Soelistyo, Hak Cipta Tanpa Hak Moral. Jakarta: Raja Grafindo Persada, 2011.

[9] R. Amrikasari, "Tata Cara Pencatatan Hak Cipta Lagu Secara Online," 2019. [Online]. Available: https://www.hukumonline.com/klinik/detail/ulasan/cl4454/tata-carapencatatan-hak-cipta-lagu-secara-ionline-i.

[10] R. Jened, Hukum Hak Cipta. Bandung: Citra Aditya Bakti, 2014.

[11] R. A. Wibowo, “Arti Sebuah Rasa Tanggung Jawab," 2013. [Online]. Available: https://www.kompasiana.com/rizkyadiwibowo/553002646ea8345e068b45ae/artisebuah-rasa-tanggung-jawab. 